\title{
The Reflections of Israeli Apology to Turkey after Mavi Marmara Crisis on Turkish Press: Examples from Daily Newspapers; Cumhuriyet, Hürriyet, Sözcü, Yeni Şafak and Zaman
}

\author{
Emre Osman Olkun \\ Research Assistant Selcuk University, \\ Communication Faculty Journalism Department Konya-Turkey \\ emreolkun@selcuk.edu.tr
}

Doi:10.5901/ajis.2013.v2n9p757

\begin{abstract}
In line with the diplomatic history began in 1949, the relations between Turkey and Israel have fluctuated from time to time until the beginning of 21st century. Issues like Davos crisis, strikes on Gaza and the humiliation of Turkish ambassador caused the relations between two countries sour particularly. The main incident that caused tension in relations occurred when Israeli forces assaulted a flotilla of aid-carrying ships, aiming to break the country's siege on Gaza, and flotilla's lead vessel Mavi Marmara on May 31, 2010. After the incident caused death of nine Turkish activists the diplomatic relations between two countries came to a stopping point. The ongoing situation for 3 years has recently taken a new dimension with Israel's apology to Turkey which meets Turkey's three basic demands. This study examines the reflections in Turkish media within the context of Mavi Marmara incident. The results of this study are based on the data collected from five newspapers Cumhuriyet, Sözcü, Yeni Şafak, Zaman and Hürriyet which are representing different political ideologies in Turkey. The study aims to examine the relevant news about Mavi Marmara incident in forenamed newspapers using the critical discourse analysis on the dates March 23, 24 and 25. According to study, newspapers with different publication policies and ideology represent news stories using different discourses.
\end{abstract}

Keywords: Relations of Turkey and Israel, Mavi Marmara Incident, Critical Discourse Analysis.

\section{Introduction}

The relations between Turkey and Israel have experienced different situations over the 60 years, even the relations was almost finished among two countries. However, especially the after Justice and Development Party (AK Party) Governments since 2002, Turkey and Israel relations have experienced the most active periods. They had so many crises in this period; many of them are still unsolved. The most important crisis between two countries is "Mavi Marmara" raid. Mavi Marmara raid was carried out in May 2010 and because of this event, relations between Turkey and Israel was almost finished. Mavi Marmara is one of the charity ship one of the members of flotilla which goes to Gazze Strip blockaded by Israel since 2006 and the main aim of this charity organization is to draw attentions from world public opinions to Gazze and stop blockade. In order to stop the flotilla, Israel army raided to Mavi Marmara and soldiers killed 9 innocent people on international water. After this, Turkey demanded formal apology and compensation for victims' families from Israel and Israel have been silent to these demands for a long time. Nonetheless, after three years from the raid Israel apologized officially from Turkey and it also declared that Israel is ready to start negotiations with Turkey to compensate Turkey's other demands.

In this study, the presentations of Turkish press for Israel's apology from Turkey because of Mavi Marmara raid will be taken in hand. In the content of the study, Mavi Marmara raid was analyzed with taking into account the historical background of Turkey-Israel relations. Beside this, the reflections of Israel's apology from Turkey were taken in hand from 5 different newspapers.

\section{The History of Turkey and Israel Relations}

Dursunoğlu (2000: 31) emphasized that Turkey and Israel relations have to be analyzed by separating three different periods. These;

1. Israel was recognized diplomatically by Turkey on 28 March 1949 but in this period, Turkey abstained from Islamic countries because of this relation and Turkey continued relations with Israel secretly.

2. In the period of 12 September 1980 military coup, relations was almost finished or stopped. 
3. In this period, with Oslo meeting Turkey developed its relations with Israel openly and intensively, at this point reactions from different countries were ignored.

Beside these three periods, a fourth period must be added that this period covers from 2002 to at that moment. Because in this period Justice and Development Party (AK Party) won elections and it has been governing Turkey for 11 years. In these 11 years, two countries have experienced a blowy relations period and after Mavi Marmara raid, which is the subject of this study, relations between two countries was almost stopped. In this part the study, historical background of Turkey and Israel relations will be analyzed briefly in a historical process.

Israel was established officially in 1948 with the supports of USA and UK which are winners of Second World War. Turkey became the first Muslim country among other Muslim countries to recognize Israel diplomatically. In this process, Turkey's siding with westerner countries and efforts of USA to develop relations between Turkey and Israel were so effective. Although Arab-Israel war and Arab-Israel conflicts were so effective to determine policies of Turkey against Israel, Turkey always had to take into account its society's demands (SDE, 2011: 4). After diplomatic recognition of Israel by Turkey, relations of two countries have developed rapidly and important developments have realized especially about military, economic and intelligence areas. However, in the shadow of Arab-Israel conflict as mentioned before, relations followed a blowy route (Yılmaz, 2010: 11).

Israel was born in a situation while hot war turning to cold war and after this wars between Israel and Arab states and Arab-Israel conflicts drawn whole attention of world to Middle East. Beside Palestinian problem's being middle of the Arab-Israel conflicts, it is also the most important parameter affecting situations and conditions in Middle East. This occasion is also valid at that moment (Üren, 2011: 4). Turkey which is caught in the middle has tried to prove its detachment against Israel and after this Turkey was declared as gendarme of west by Turkish public opinions and Arab neighbors. With Israel's being an actor in Middle East, Turkey's role and image of being effective when it is necessary or assigned by west in the Middle East was injured severely (Çoşkun, 2010: 457).

Ateş (2012: 86) stated that the relations between Turkey and Israel was normal among 1949-1955 but the relations started to be damaged after Baghdad Pact in 1955. Baghdad Pact was signed among Turkey, Iraq, Iran, Pakistan and United Kingdom and it aimed to decrease effectiveness of the Soviet Union in the Middle East. At this point, Turkey rearranged its relations with Arab states and Turkey also tried to balance its relations with Israel. Moreover, the role of Israel in Suez Canal on 26 November 1956 was considered by Turkey and it changed its relations with Israel in charge d'affaires level.

After 1960s, Turkey started to carry out balanced policy which generally supported Arab states especially after the effects of Cyprus problem and its economic difficulties and Turkey started to implement this policy after second part of 1960s (YIImaz, 2010: 13). Turkey's taking position on the side of Arab states shows and proves its policy in these years. After Arab-Israel war, Turkey continued this attitude against Israel. Especially, Israel's attacks to down Al Aksa Mosque strengthen and toughened Turkey policy against Israel (SDE, 2011: 9).

After the second half of 1970s, Turkey developed its relations with Arab states and Soviet Union and it started to experience political problems in its relations with USA. Another feature of this period is that Palestine Liberalization Organization established in 1964 and became powerful and its actions started to affect the relations between Turkey and Israel. In November 1975, Turkey voted in favor of accepting Zionism as a kind of racism and racial discrimination in United Nations. This caused to affect the relations with Israel negatively. Also Israel's occupation the south Lebanon in March 1978 started another problematic period in Turkey-Israel relations. In July 1980, against declaration of Israel about Jerusalem as timeless capital, Turkey showed a strong respond and it closed its legation in Jerusalem. Also National Security Council of Turkey reacted to change the diplomatic relations in secondary secretary level because of Israel declaration about Jerusalem as timeless capital of Israel state (Özcan, 2001: 164-165).

In parallel with developments in international relations, after second part of 1980 s Turkey-Israel relations have entered into the period of softening. Actually Prime Minister Turgut Özal played a crucial role for softening the relations among these countries (YIImaz, 2010: 14). In this period, the most important obstacle in front of the improvement of Turkey-Israel relations was Palestine problem and its being unsolved. However, developments achieved in these years made relations positive compared with before. Peace process starting with Madrid Conference and following the Oslo Deal affected Turkey-Israel relations positively. Turkey changed its relations with Israel to embassy level in December 1991. In this process, peace process started after October 1991 and new international environment was so effective (Kasım, 2001: 574).

1990s witnessed the improvements in relations between Turkey and Israel. In 1992, Ezer Wiesman's official visit for Turkey because of $500^{\text {th }}$ years of Jews' coming to Ottoman territory from Spain shows the importance of civil society activities between Turkey and Israel (Ateş, 2012: 86). Relations between two countries became intense in 1993. The reason of this, treaty confirming Oslo Peace Process was signed in 1993. This situation provides Turkey to act more 
comfortable for improving its relations with Israel. Hikmet Çetin became the first Turkish Minister of Foreign Affairs visiting Israel in 1993 and one year latter Ezer Wiezman visited Turkey in 1994. In the same year, Simon Perez Israel Minister of Foreign Affairs visited to Turkey and in October Turkish Prime Minister Tansu Çiller visited officially to Israel (Kasım, 2001: 571).

Military Training Cooperation Agreement on 23 February 1996 and Defense Industry Cooperation Treaty on 28 August 1996 were signed between Turkey and Israel. Strategic meeting for every sixth month, Mossad's supports to Turkey's problem with Syria for catching Abdullah Öcalan, first-aid and rescue support by Israel for Marmara earthquake in 1999 were the key points of convergence realizing in that period (Ateş, 2012: 86-87). Convergence of Turkey and Israel throughout 1990s entered a slowdown period and it turned a crisis at the end of 1990s. In parallel with happening in Palestine problem, Turkey Prime Minister Bülent Ecevit blamed Israel with slaughter and this increased the tension between two countries and this situation continued throughout 2000s (Tür, 2013: 27). Beside this, not being solved Palestine-Israel problem, Israel's public opinions turning into politically fundamentalist and extreme right, policies of Israel governments caused to deteriorate the relation of Turkey-Israel while entering 2000s.

In 2000s Justice and Development Party won elections and got political power and because of policy change in Turkish foreign affairs Turkey's field of interest enlarged. That is why; not only international but also regional circumstances were instrumental in shaping the relation of two countries (Üren, 2011: 3). The period of 1999-2009 should be taken in hand as a problematic and crisis period but in this period each country took some steps and turned the relation into normal situation (Tür, 2013: 27). However, events realized between Turkey and Israel from 2009 to at this moment caused the relation to turn into a crisis environment. The most important and also determinant event in this period is "Mavi Marmara" raid in 2010.

\section{Mavi Marmara Raid}

Israel Army carried out a raid to flotilla consisting 6 ships which carrying humanitarian aid to Gazze Strip blockaded by Israel for 4 years, especially army attacked Mavi Marmara ship having 6 hundreds passengers and 3 hundreds 47 of them Turkish citizens on international waters on 31 May 2010. Israel armed forces named this operation as "sea breeze" and they killed 9 innocent and unarmed Turkish people on Mavi Marmara and also hundreds were arrested by Israel (Reçber and Öğüt, 2012: 508). Justice and Development Party Government's clear support to Palestine and especially Hamas government in Gazze, "One Minute" crisis at Davos in 2009, diplomatic crisis between Israel Minister of Foreign Affairs and Turkish Ambassador played determinant role to deteriorate relations of two countries. However, events coming relations to breaking point is the raid of Israel army to Mavi Marmara which aimed to stop blockade to Gazze Strip by Israel and in this raid 9 people were killed (Yalın, et all. 2012: 228). When raid was carried out, Turkish Prime Minister and Minister of Foreign Affairs in South America and President Abdullah Gül was also abroad because of another program. After this tragic events, Prime Minister, and Turkish President stopped their programs and returned to the country and Ahmet Davutoğlu Minister of Foreign Affairs went to New York and Turkey asked United Nations Security Council for urgent meeting. After Turkey's call, United Nations Security Council gathered and declared a condemnation notice for Israel (SDE, 2011: 18).

With Mavi Marmara raid, Turkey and Israel, which had been strategic mutual in 1990s, came up against twice times. When looked this point, it can be said that relations of two countries were damaged and it seems that these effects will be going on. After Mavi Marmara raid, Turkey withdrawn its Israel Ambassador and stopped diplomatic relations. Beside this, Turkey also demanded Israel three conditions to start relations again. These conditions are;

1. Official Apology,

2. Compensation for 9 Turkish People killed during the raid by Israel soldiers,

3. Remove the embargo for Gazze Strip by Israel (Şahin, 2011: 24)

Israel have not accepted Turkey's demands and it have made respond for along time and it also defended its justness about interference to the flotilla. Not squandering time, Turkish Government declared how its attitude will be against Israel in the explanations of Ahmet Davutoğlu Minister of Foreign Affairs. Turkey's decisions about process are these;

1. Turkey changed its official relation level with Israel to secondary secretary level. Other officials will come back to Turkey especially ambassador until Wednesday.

2. Whole military treaties signed Israel before were suspended by Turkey.

3. Turkey which has the longest short in east Mediterranean will take every necessary precautions for navigation independence in this region. 
4. Turkey does not recognize officially Israel's blockade to Gazze Strip. Turkey after 31 May 2010 will try to convince International Court of Justice to analyze Israel illegal blockade for Gazze Strip. In parallel to this, Turkey will make United Nations act responsibly.

5. Turkey will also support witness and victims of Israel attacks to seek justice in courts (Şahin, 2011: 26).

After Mavi Marmara raid Israel have been silent and oblivious to apology and compensations demands of Turkey and this has taken the relations away in fragile and unsolved situation. Although military treaties were suspended and diplomatic relation was turned into secondary secretary level by Turkey and this is a familiar situation for two country; Turkish and Israel public opinions and relations were damaged seriously in terms of polarization and being biased (Ateş, 2012: 87).

During USA President Barack Obama's visit to Israel on 22 March 2013, Israel Prime Minister Benjamin Netanyahu apologized officially from Turkey by calling Turkish Prime Minister Erdogan for Mavi Marmara raid. After this conversation which Obama witnessed, Israel Ministry of Foreign Affairs declared official apology from Turkey to world public opinion (Tür, 2013: 27).

\section{Method}

After Mavi Marmara raid carried out 31 May 2010, Israel apologized officially from Turkey on 22 March 2013 and this found a big echo in Turkish press and newspapers gave big places for this news on their pages. This study takes in hand reflections of Israel's official apology from Turkey in Turkish press. As sampling for the study 5 different newspapers from different ideological perspectives were selected and they will be analyzed for 3 days after the apology declaration. These Turkish newspapers are Cumhuriyet, Sözcü, Yeni Şafak, Zaman and Hürriyet. Cumhuriyet and Sözcü represent leftistnationalist ideology, Zaman and Yeni Şafak represent conservative and right ideology, Hürriyet represents main stream media in the content of the study.

In the study, news of these five newspapers about Israel's official apology from Turkey because of Mavi Marmara raid was analyzed according to critical discourse analysis method. News schedule includes the dates of 23-24-25 March 2013. Critical discourse analysis method was used to state that how Turkish press took in hand the Israel's apology and how they represented the event and also by using this method it was aimed to make clear relation between news language and discourse.

Although news generally depends on real stories, it is passed through from journalist's perspective and it is also processed in the mind of journalist. At this point we can take the event which is subject the news as raw materials of news. This raw material is converted news by processing in the environment of journalist's mind, perception, comment and evaluation. Journalist gathers information by observing events, collecting knowledge from witnesses, news sources, sides of events and than he or she converts these materials into news by processing them in his or her cognitive process. Consequently, news text goes beyond the being complete reflection of event. In fact news produced by media can only be fiction narrative which is formed in some productive processes and is fed by real events although they depend on real events or stories. According to van Dijk, producers must be taken into account when these texts are analyzed (Güngör, 2011: 213-214).

Discourse analysis of van Dijk is a kind of analysis which takes texts in hand in terms of propositions. This method is accepted in the content of critical studies and it takes news in hand in terms of so many different points of views. Teun van Dijk formed theoretical and practical background of Critical Discourse Analyze Method and according to his idea news must be taken in hand as context and social production. van Dijk also analyzes discourse as ideologically and especially he focuses on social cognitions. These cognitions are counterparts of the terms of consciousness, production of meaning or perception (Mora, 2011: 18). According to Güngör (2011: 214) while van Dijk emphasized that news discourse forms in a social environment, idea situation and ideological structure of social environment are more effective on the formation of discourse. van Dijk has developed a dual structure for discourse analysis as Macro and Micro.

Mora (2011: 20-21) states van Dijk's Macro and Micro structures like this:

Macro Structures; are separated two parts as thematic and schematic structures.

1. Thematic Structure: Top title, title, subtitle, spot and news entrance; title and news entrance; beside summarization, they play a role as summary. Analysis of standard news consisting title, spot and news entrances shows that news is a hierarchic system which shapes news from important to less important and from general to special.

2. Schematic Structure: This part includes information about news event and it evaluates how news was taken in hand. It may also include context and background information. Verbal reactions of event's sides and news 
sources can be given place in this part. Associations like government, courts etc. are macro structures and newspaper is connected with micro structures.

Micro Structures:

1. Syntactic structure.

2. Regional coherence among words; this structure analyzes relations of words repeatedly come with each other.

3. Words selections; selected words reflects ideology of newspaper and journalist.

4. Rhetoric analysis of news; length or shortness of sentences used in news, simplicity or complexity of sentences, activity or passivity of sentences, photos, graphics increasing reliability of news, numbers, data and news rhetoric make clear ideological structure of news. Micro structures are journalists, demonstrators and minorities.

\section{Findings}

\subsection{Discourse Analysis of News Published by CUMHURIYET}

One day after the event on 23 March 2013 Cumhuriyet published its first news about the event on first page and it was elaborated inside pages. Newspaper serviced its news to readers with using the title of "Obama reconciled" and top title of "Netanyahu apologized for Mavi Marmara. Erdoğan accepted it". The statement of "Obama reconciled" used as news title tells that main reason of this apology is President Barrack Obama". Beside this, newspaper also wants to show the statement of Obama's message focusing regional alliance of Turkey and Israel was evaluated as a sign of his Middle East project as main reason of the apology. It is also remarkable that apology of Israel from Turkey, which is so important for Turkish and world public opinions, was taken in hand on first page but not as headline by Cumhuriyet.

At this time on 24 March 2013 newspaper published second news on its headline about the event with using title of "USA got something out of this" and subtitle of Apology of Israel accepted as a victory by Turkey keeps secret Middle East plans of Obama from people". "Interests outbalanced" is another statement highlighted in news discourse by newspaper. Newspaper also highlighted that this apology is not a success of Turkey's diplomatic effort, contrary to this; it is an attempt of USA in accordance with USA's interest in Middle East. Also inside part of the news, newspaper used the title of "interests, interests, interests..." to support its general news discourse.

On the third day of the event, Cumhuriyet did not publish any news about the event. In addition to this, columnists of newspaper also did not write anything about the event which took a huge place on international media organization.

\subsection{Discourse Analysis of News Published by SÖZCÜ}

On 23 March 2013 Sözcü serviced Israel's official apology from Turkey to its readers as news on a small part of first page. News also published as so small inside pages. Newspaper used the title of "Obama made Israel apologize" and it published a photo showing Obama, Erdoğan and Netanyahu together. Newspaper also used a remarkable sentence "They will be very close in a short time" under the photo. With using the statement of "Obama made Israel apologize" newspapers tried to produce a discourse implying that Israel did not apologize inherently from Turkey, Obama made Israel apologize from Turkey. Continuation of the news, newspaper emphasized the relations of Turkey-USA and Israel and that is why, Israel's apology hide different purposes its behind. Similarly Cumhuriyet, Sözcü did not publish this important news on its headline or middle of the first page. Moreover, newspaper did not use any specific news source for its news and it used some passive word structures and citations as news source.

On 24 March 2013, Sözcü published a news in its inside page with using the title of "At first Obama talked with Erdoğan and than he gave the phone to Netanyahu". By doing this, newspaper wanted to strengthen its general news discourse claiming that the apology was organized by Obama and Israel did not inherently do this. Beside this newspaper claimed that main reason of the apology is alliance and mutual interests of Turkey, USA and Israel in Syria and newspaper supported this claim by using some indirect citations from international media.

On 25 March 2013, at this time Sözcü published its news about the event on the first page by using the title of "Government will corporate with blood killers" and it also gave a message to its readers by using subtitle of "Israel confessed why it apologized from Turkey". Newspaper also strengthened its general news discourse with using a photo of Obama and Netanyahu and under the photo newspaper used the statement of "Turkish Government and Israel will attack Basher Al-Assad together. Continuation of the news, newspaper used the title of "Intervention team is preparing" and in the content of news newspapers used statement of "Israel Prime Minister Netanyahu apologized from Erdoğan in order to cooperate with Turkey against Syria". When thematic structure of news is analyzed, newspaper tried to produce 
a discourse implying that Israel apologized from Turkey because of its regional interests and also newspaper defined Israel and USA as bloody killer in its news discourse. In general, newspaper embraced a biased publication policy because of it bad relations with Turkish Government and that is why it tried to reflect the event not a success. It reflected the event as a secret treaty among Israel-Turkey and USA against Syria. It used a problematic language structure to produce its biased news discourse and newspaper did not use so many news sources for its news.

\subsection{Discourse Analysis of News Published by HÜRRIYET}

Hürriyet announced its first news about Israel apology from Turkey on its headline with using title of "Apology Victory" on 23 March 2013. Newspaper reflected evidently this news as a diplomatic victory of Turkish Government with using supportive titles and subtitles such as "Victory", "We are ready to pay compensation", "Turkey's got its demands".

In continuation of the news, newspaper gave a huge place to explanations of Turkish Prime Minister Recep Tayyip Erdoğan and Minister of Foreign Affairs Ahmet Davutoğlu. In schematic structure of news, these explanations were highlighted on news discourse and also news discourse implied that Turkey directed this process so successful and that is why Turkey got its rightful demands. In addition to this, newspaper gave detailed information about the process to highlight Turkish Government's success and it also stated that Israel have apologized only two country so far except Turkey.

On 24 March 2013, by publishing so much news about the event on its economy, agenda and foreign news pages; newspaper tried to show its pleasure about the event. The news published on headline with title of "At first compensation and than Ambassador" tells that normalization about relations with Israel, Turkey make Israel accept the compensation for killed people's families. Beside this, in order to strengthen its news discourse, newspaper used news from international media by making citations.

On 25 March 2013, Hürriyet did not publish any news about the apology but it published a reportage on headline with Israel President Şimon Peres about Turkey-Israel relations. In this reportage newspaper highlighted the relations between Turkey and Israel and it used Peres's sentence emphasizing to forget past "past is dead" as news spot.

\subsection{Discourse Analysis of News Published by YENI ŞAFAK}

On 23 March 2013, newspaper published its first news on first page about Israel apology with using titles of "Turkey made Israel apologize" and "Gazze martyrs reached their goals". Newspaper produced its discourse according to acceptance of "Turkey forced Israel to apologize". Moreover, newspaper used photos of 9 people killed in Mavi Marmara and to remind its readers the background of the raid. Newspaper also emphasized Turkey's diplomatic success against Israel with using subtitles of "Israel also will pay compensation" and "Gazze blockade will be stopped" to produce superiority upon Israel in news discourse. to strengthen this discourse, newspaper also used a photo showing Israel Prime Minister Netanyahu as tearful. Newspaper evidently reflected the event as a diplomatic victory of Turkey and in news discourse it frequently used some kind of word structures such as "Turkey made Israel knell down" to exaggerate situation for news discourse. Newspaper used the word of "martyr" to define victims killed by Israel soldiers.

Newspaper went on to publish so much news about the event on 24 March 2013 in its pages. In one of the news, Yeni Şafak highlighted Erdoğan's sentence "I did not answer the phone until apology written on official document". Also newspaper gave a huge place in its news to first reactions of international media. It supported its general news discourse by giving place to explanations of so many academicians about the process and this news was published by using the title of "World saw the power of Turkey".

On 25 March 2013, newspaper used explanations of vice president of Justice and Development Party Mevlüt Çavuşoğlu. In this news newspaper highlighted Çavuşoğlu's sentence "Israel's apology proved our rightful to whole world" as news title and by doing this newspaper embraced news discourse as normal. News discourse was framed according to these explanations and that is why newspaper caused a semantic closure in behalf of news source. During these three days, newspaper published so much news about the apology and it generally embraced a news discourse that highlighted the apology as a diplomatic victory of Turkey and world appreciated Turkey because of this apology. Moreover, in news discourse newspaper so many times tried to legitimize Turkish Government's policy about this process.

\subsection{Discourse Analysis of News Published by ZAMAN}

Last newspaper analyzed in the content of the study is Zaman. Newspaper announced the apology on its headline by 
using title of "Apology and Compensation from Israel". Newspaper highlighted acceptance of whole conditions of Turkey by Israel and according to newspaper Obama played a crucial role for this process. Newspaper also emphasized that main reason of agreement between two countries is increase of Iran in Syria and Middle East.

On 24 March 2013, newspaper published different news on its headline with using the title of "Arab World echoed with apology". In continuation of news inside pages, newspapers gave huge place to explanations of Arab World and in news discourse it was highlighted that Arab World perceived the apology as success of Turkey and Islam world. In news, newspaper used the title of "Spring in USA after apology" and newspaper gave place to explanations of officials form USA to prove USA's gladness to normalization of Israel and Turkey.

On 25 March 2013, newspaper turned Prime Minister Erdoğan's explanations into news with using title of "Relations will turn normal if implementations are done". During three days, newspaper gave a huge place to Israel's apology and newspaper embraced general news discourse highlighting Turkey's success against Israel.

\section{Conclusion and Discussion}

This study tried to analyze the reflections of Israel's official apology from Turkey for Mavi Marmara raid in Turkish press by using critical discourse analysis. According to analysis, it was found that newspapers from different political, editorial and ideological perspectives used different kinds of discourse to transfer news to their readers.

Cumhuriyet and Sözcü did not pay more attention to Israel's apology in this process and their news discourse claimed that this is not a victory and Turkish Government did not win anything in this process. These newspapers reflected this process as interests of USA and Israel and according to their news discourse Israel did not apology inherently from Turkey. Yeni Şafak and Zaman published so much news during this process and also news highlighted the process as diplomatic victory of Turkish Government. Especially, Yeni Şafak published so much news to show this process as victory of Justice and Development Party Government.

Hürriyet published so much news and it designed its news discourses on the acceptance that this is a victory of Turkish Government and this process will normalize the relations of Turkey- Israel.

In this study five different newspapers from different ideology were analyzed and although this is a national problem, newspapers generally tried to reflect their own ideologies. This situation proved and supported hypothesis of the study.

\section{References}

Ateş, Ahmet Emre (2012). Türkiye-İsrail Ilişkilerinde Gerilimin Nedenleri ve Sürekliliği. II. Bölgesel Sorunlar ve Türkiye Sempozyumu 1-2 Ekim 2012, 85-88.

Çoşkun, Bezen Balamir (2010). İran-İsrail Ekseninde, Türk Dış Politikasının Analizi. (Editör: Cüneyt Yenigün ve Ertan Efegil). Türkiye'nin Değişen Dış Politikası. Ankara: Nobel Yayın, 451-467.

Dursunoğlu, Alptekin (2000). Stratejik Ittifak Türkiye-Israil Ilişkilerinin Öyküsü. İstanbul: Anka Yayınları.

Eroğlu Yalın, Bahar, Bayram, Yavuz ve Bekiroğlu, Onur (2012). Uluslararası Çatışma Olarak Mavi Marmara Olayı'nın Türk Yazıı Basınında Sunumu ve Toplumsal Siyasetin Üretilmesine Etkisi: Cumhuriyet, Hürriyet ve Zaman Gazetesi Örnekleri. Turgut Özal Uluslararası Ekonomi ve Siyaset Kongresi II. Küresel Değişim ve Demokratikleşme Bildiriler Kitabı. İnönü Üniversitesi İktisadi ve Idari Bilimler Fakültesi, 227-243.

Güngör, Nazife (2011. İletişim Kuramlar Yaklaşımlar. Ankara: Siyasal Kitapevi.

Kasım, Kamer (2001). Türk-Israil İlişkileri: İki Bölgesel Gücün Stratejik Ortaklığı. (Editör: İdris Bal). 21. Yüzylıın Eşiğinde Türk Dış Politikası. İstanbul: Alfa Yayınları, 569-581.

Mora, Necla (2011). Medya Çalışmaları Medya Pedagojisi ve Küresel Illetişim. Ankara: Nobel Yayın.

Özcan, Gencer (2001). Türkiye-Israil İlişkileri 50. Yılına Girerken. (Editör: Faruk Sönmezoğlu) Türk Dış Politikasının Analizi. İstanbul: Der Yayınevi, 159-177.

Reçber, Sercan ve Öğüt, Selman (2012). Mavi Marmara Olayının Uluslararası Hukuk Açısından Değerlendirilmesi. İstanbul Ticaret Üniversitesi Sosyal Bilimler Dergisi Yıl: 11 Sayı: 22 Güz 2012/2. 507- 520.

SDE Analiz, Türkiye-Israil Iliş̧kileri, Ekim 2011, www.sde.org.tr/userfiles/file/TURKIYE \%20ISRAIL\%20ILISKILERI.pdf (Erişim Tarihi: 10 Temmuz 2013).

Şahin, Mehmet (2011). Türkiye-İsrail Ilişkileri: Zoraki Ittifak Çöktü. OrtadoğuAnaliz, Eylül 2011, Cilt: 3, Sayı: 33, 22-29.

Tür, Özlem (2013). İsrail'in Özür Dilemesi Sonrası Türkiye-İsrail Ilişkileri. Ortadoğu Analiz Haziran 2013, Cilt:5-Sayı:54, 26-34.

Üren, Mustafa (2011). AK Parti İktidarı Dönemi Türkiye-İsrail lişskileri. International Middle East Peace Research Center, Rapor No: 10.

YıImaz, Türel (2010). Türkiye-Israil Ilişkileri: Tarihten Günümüze. Akademik Orta Doğu, Cilt, 5, Sayı, 1, 9-24. 